\title{
Assessment of barriers to establish OSH: a country report
}

\author{
Hadi ARASTOO ${ }^{1 *}$, Azimov Pulod HAKIMOVICH ${ }^{2}$ and Soraya ESFANDIARPOUR ${ }^{3}$ \\ ${ }^{1}$ Academy of Sciences of The Republic of Tajikistan, Tajikistan \\ ${ }^{2}$ Tajik Technical University, Tajikistan \\ ${ }^{3}$ Izlamic Azad University of Science and Research of Khouzestan, Tajikistan
}

Received December 22, 2013 and accepted March 30, 2015

Published online in J-STAGE April 24, 2015

\begin{abstract}
In addition to its merits, industrial growth is associated with many issues and problems, including occupational injuries and diseases. The adverse effects of industrialization are function of economic, social, cultural, political and geographical condition of a country, and therefore it varies widely between different countries, especially, developed and developing countries. Establishment of occupational safety and health $(\mathrm{OSH})$ is one of the important solutions to predict, prevent, reduce and harness of the related harms. Despite many relevant protocols and guidelines for establishment of OSH and decades of efforts, still, there are debates and lack of success on different approaches towards implementation of $\mathrm{OSH}$, especially in developing countries. Iran has experienced industrialized growth and has gained some advancement in establishment of OSH in the region. The purpose of this study was to reach to a consensus among Iranian experts about barriers to establish OSH in developing countries, using Delphi technique. 48 experts participated in this study. Two rounds of Delphi were conducted and main barriers were identified, then the identified barriers were prioritized and weighted by the experts. Among all barriers, 17 barriers which were reported by 15 experts or more were selected and categorized as structural, managerial and implementation barriers.
\end{abstract}

Key words: Consensus, Industrial growth issues and problems, Barriers to establishment of occupational safety and health

\section{Introduction}

In addition to its merits, industrial growth is associated with many issues and problems, including increase in occupational injuries and diseases ${ }^{1}$. Industrial growth imposes many irrecoverable damages to the environment, society and human health. Using modern technology costs a lot to the people of the world. Based on the report of ILO in Brasilia conference, in the year 1999, 250 million occu-

*To whom correspondence should be addressed.

E-mail: hadi.arastoo@gmail.com

(C)2015 National Institute of Occupational Safety and Health pational related injury events have resulted in one million deaths. In the same year, the total cost of occupational diseases, compensation for accident victims and rescuers wage costs, was equal to $4 \%$ of world GDP, which increased to $5 \%$ of GDP in the year $2008^{2)}$. Based on the ILO estimates, the annual mortality due to work-related accidents or diseases is 2.34 million, and 317 million individuals suffer from work-related injuries each year ${ }^{3)}$. It is estimated that $98 \%$ of occupational injuries is prevent$a^{a b l e}{ }^{4}$. Decision makers, legislators and authorities make endeavour to predict, prevent and reduce the harmful effects of industrial growth, and at the same time increase its benefits to the countries ${ }^{5)}$. 
Despite many relevant protocols and guideline for establishment of OSH management systems ${ }^{2,3,6-8)}$ and decades of efforts, still there is debates and lack of success on the different approaches to the implementation of OSH management systems, especially for developing countries ${ }^{9}$.

Establishment of OSH is one of the important solutions to predict, prevent, reduce and harness the related harms; and its role in development and maintain of industry and investment, increase productivity, employee and employer satisfaction and sustainable development has been proved $^{2)}$.

Due to the differences in social and economic status, resources, political views, and stages and types of industrialization, there is a huge variation in the establishment of OSH among different countries; and this variation is more dramatic and gross between developing and developed countries ${ }^{6,10)}$. Providing a desirable condition for establishment of OSH, considering special issues of each country, is one of the main solution to reach sustainable development and prevent harmful effects of industrial growth. Assessing and analysing the main barriers to the establishment of OSH in developing is an important issue that can help decision makers and health authorities to overcome these challenges and plan for removing these barriers.

Iran is one of the developing countries that are experiencing industrialization. Modern industrialization in Iran goes back to $82 \mathrm{yr}$ ago when the construction of trans-Iranian railway was started. Against many achievement and advancement in establishment of OSH in Iran, compared to other countries in the region, the burden of occupational diseases, injuries and mortality is high in Iran. Labour law 1990 of Iran compromises 203 sections and 121 subsections, and was replaced by the former labour law of 1958 . Based on this law Ministry of Labour and Social Affairs is in charge of OSH and Ministry of Health and Medical Education is responsible for health of workers. In Iran, organizations must obey OSH regulations and rules but there is no obligation to follow international standards like OHSAS 18001 standard $^{11)}$.

The Delphi method is a structured, systematic, interactive forecasting method of communication between a panel of experts. It consisted of two or more rounds of expressing opinions on some questions. After each round, a facilitator provides a summary of the experts' views from the previous round, and then experts are requested to revise their earlier answers considering the views and opinions of other participating experts ${ }^{12,13)}$.

The purpose of this study was to reach to a consensus among Iranian experts about the barriers to establishment

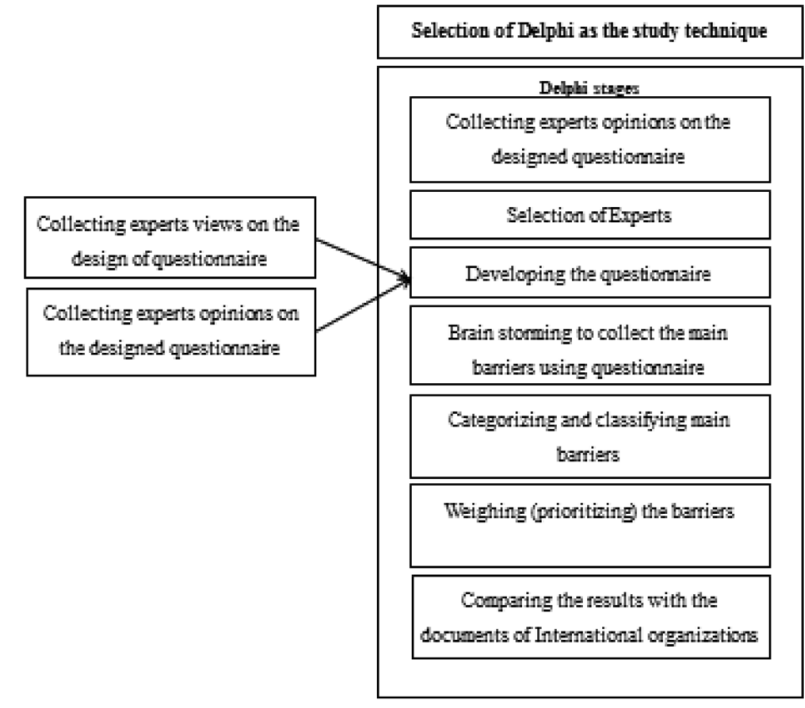

Fig. 1. The study procedure flowchart.

of OSH in developing countries using Delphi technique, and also to propose key strategies to deal with the threats ahead and take advantage of optimal results.

\section{Subjects and Methods}

To collect information about barriers to establishment of OSH in developing countries and in order to reach to a consensus on this issue among experts, Delphi technique was used. Figure 1 shows the flowchart of the study procedure (Fig. 1).

\section{Participants}

Study experts were selected using the data bases enlisting faculties of relevant universities, experts and researchers in Ministry of Health and Medical Education, Ministry of Work and Social Affairs, Research Centres and the Centre of Research and Education of Ministry of Work and Social Affairs and also through personal experiences and snowballing of different experts. The below criteria was used for selection of experts:

- Master level or higher educational degree in safety and occupational health, industrial safety, occupational medicine, Health, Safety and Environment (HSE)

- More than ten years work experience

- Current and previous positions in administrative work

- Having publication/s (manuscript in scientific journals or books)

- Association with international organization/s, work experience or education history abroad

- Work at a national level organization 
Table 1. Showed the selected experts characteristics

\begin{tabular}{lc}
\multicolumn{1}{c}{ Characteristics } & Number of experts \\
\hline Academic Profile & 24 \\
PhD in Occupational Health & 8 \\
Master of Engineering (ME) in Safety and Occupational Health & 2 \\
PhD in environmental Health (Engineering, Safety and Occupational Health) & 10 \\
Specialist in Occupational Medicine & 4 \\
ME from different related disciplines with work experience in safety and occupational health & \\
Occupational profile & 34 \\
Faculties of Universities (12 HOD - 11 Dean) & 3 \\
Executive board in Ministry of Health and Medical Education & 5 \\
Executive board of Occupational safety and Research Centre of Ministry of Work and social & \\
Affaires & 3 \\
The managers and directors of HSE in Iran Petroleum Company & 2 \\
The managers and directors of HSE in Iran steel industry & 1 \\
The managers and directors of HSE execution in different industries & $48(100)$ \\
Total & \\
\hline
\end{tabular}

Sixty two experts were identified in Iran, using these criteria, but further investigation showed that 10 of them do not have $10 \mathrm{yr}$ of work experience and therefore were excluded from the study and the rest of 52 experts were included in the study (Table 1).

The average age group of participants was $54.8 \mathrm{yr}$ (33$63 \mathrm{yr})$ and the average working experience was $21.2 \mathrm{yr}$ (10-35 yr). On average these group published 4.8 books per expert (1-18 books) and on average 34 articles per expert (1-more than 100) (Table 1).

\section{Data collection tools}

Two different questionnaires were used in this study. First questionnaire was used for brain storming among experts about the main open question "What are the main barriers towards establishment of OSH in developing countries?" The second questionnaire was used to weigh and prioritize the identified barriers in the first stage.

\section{Data collection procedure}

The first questionnaire was sent to 52 selected experts, which 48 have responded. To ensure maximum participation, questionnaire was sent by email, fax and post and sometimes through personal contact of the researchers.

The responses of 48 experts were coded, categorized and analysed into items (barriers). Many identified barriers were similar among 48 experts' opinion and therefore, those items with average number of repetitions (a frequency more than 15 times repetition in the experts' opinion meaning agreement of around $30 \%$ of experts on that item) were included in the next stage questionnaire to be weighted and prioritized. Five experts conducted and reviewed this stage of the research and prepared the second questionnaire. Then, again three other experts reviewed the second stage questionnaire and finalized it. The finalized questionnaire was sent to 48 experts that had replied to the first round of study that 43 of them replied to the second questionnaire. The Delphi was ended in these two rounds because of very difficult process of access to these experts and convincing them to reply to the questionnaires.

\section{Statistical analysis}

Statistical package for social sciences (SPSS) version 19.0 for windows (IBM Corporation, New York, USA) was used to analyse the data. Descriptive statistics (percentage and frequency) and Friedman test were used to analyse the data.

\section{Results}

Table 2 shows the results of two rounds of Delphi study on experts' views about barriers towards establishment of OSH in developing countries. Lack of awareness and knowledge of employers, managers, health workers towards work safety and occupational health was the main barrier towards establishment of OSH in workplaces which was expressed by all the experts with the mean importance of 7.16 followed by inadequacy of the inspection system, lack of adequate and effective inspection and supervision on OSH activities which was reported by 47 experts (97.9\%) with a mean importance of 7.13 and in the third place there was lack, deficiency, weakness or absence of 
Table 2. Barriers towards establishment of occupational safety and health in developing countries (results of two rounds of Delphi)

\begin{tabular}{|c|c|c|c|c|c|}
\hline & \multirow{2}{*}{$\begin{array}{l}\text { Barriers towards establishment of occupational } \\
\text { safety and health in developing countries }\end{array}$} & \multicolumn{2}{|c|}{ First round } & \multicolumn{2}{|c|}{ Second round } \\
\hline & & $\begin{array}{l}\text { Frequencies } \\
\text { of repetition }\end{array}$ & $\begin{array}{l}\text { Percent of } \\
\text { agreement }\end{array}$ & $\begin{array}{c}\text { Mean } \\
\text { importance }\end{array}$ & $\begin{array}{l}\text { Friedman } \\
\text { test rank }\end{array}$ \\
\hline 1 & $\begin{array}{l}\text { Lack of awareness and knowledge of employers, managers, health workers towards work } \\
\text { safety and occupational health }\end{array}$ & 48 & 100 & 7.16 & 1 \\
\hline 2 & $\begin{array}{l}\text { Inadequacy of the inspection system, lack of adequate and effective inspection and } \\
\text { supervision on occupational safety and health activities }\end{array}$ & 47 & 97.7 & 7.13 & 2 \\
\hline 3 & $\begin{array}{l}\text { Lack, deficiency, weakness or absence of legislation on occupational safety and health } \\
\text { (absence or lack of binding rules and lack of up-to-date regulations) }\end{array}$ & 38 & 79.1 & 5.66 & 12 \\
\hline 4 & $\begin{array}{l}\text { Lack of participation, interaction and active involvement of governments with employers } \\
\text { and employees on establishment of occupational safety and health }\end{array}$ & 34 & 70.8 & 6.18 & 6 \\
\hline 5 & Existence of financial constraints and weak economy & 34 & 70.8 & 6.76 & 3 \\
\hline 6 & $\begin{array}{l}\text { Multiplicity of occupational safety and health stewardship (multiplicity of task-based } \\
\text { organizations) }\end{array}$ & 30 & 62.5 & 5.76 & 11 \\
\hline 7 & $\begin{array}{l}\text { Insufficient knowledge and skills of graduates, and sometimes irrelevancy of their } \\
\text { knowledge to the needs and requirements of workplace }\end{array}$ & 25 & 52 & 6.16 & 7 \\
\hline 8 & $\begin{array}{l}\text { Lack of a coherent plan, modern strategies and appropriate vision for occupational safety } \\
\text { and health programs (lack of a comprehensive national program) }\end{array}$ & 25 & 52 & 6.74 & 4 \\
\hline 9 & $\begin{array}{l}\text { Non-compliance with laws and regulations, lack of enforcement due to ignorance, } \\
\text { incorrect and profitable relationships or corruption }\end{array}$ & 24 & 50 & 6.06 & 8 \\
\hline 10 & $\begin{array}{l}\text { Lack of knowledge of employers and industry leaders and organizations managers of their } \\
\text { duties towards implementation of the labour law, and the consequences of non-compliance } \\
\text { with occupational safety and health regulations }\end{array}$ & 22 & 45.8 & 6.02 & 9 \\
\hline 11 & $\begin{array}{l}\text { Failure to establish and promote a culture of prevention in the field of occupational safety } \\
\text { and health }\end{array}$ & 22 & 45.8 & 6.30 & 5 \\
\hline 12 & Considering safety and health issues as cost rather than investment & 20 & 41.6 & 7.16 & 1 \\
\hline 13 & Absence or lack of national standards and basic or applied researches & 18 & 37.5 & 5.48 & 13 \\
\hline 14 & $\begin{array}{l}\text { Ignoring needs to protect human resources because of high level of unemployment, } \\
\text { economic conditions and lack of knowledge }\end{array}$ & 18 & 37.5 & 5.83 & 10 \\
\hline 15 & $\begin{array}{l}\text { Social, economic and managerial underdevelopment (lack of proper infrastructure and } \\
\text { inadequate infrastructure) }\end{array}$ & 16 & 33.3 & 6.16 & 7 \\
\hline 16 & $\begin{array}{l}\text { lack of databases bank, information and dissemination systems on work-related injuries } \\
\text { and illnesses and other safety and health related information (insufficient information and } \\
\text { publication sources and information technologies) }\end{array}$ & 15 & 31.25 & 5.83 & 10 \\
\hline 17 & Shortage of skilled and efficient manpower in safety and health professions & 15 & 31.25 & 5 & 14 \\
\hline
\end{tabular}

legislation on OSH (absence or lack of binding rules and lack of up-to-date regulations) which was reported by 38 experts $(79.1 \%)$ with a mean importance of 5.66 and the rank of 12 in the Friedman test. The following were lack of participation, interaction and active involvement of governments with employers and employees on establishment of OSH, existence of financial constraints and weak economy, which were mentioned by 34 experts $(70.8 \%)$.

The lowest frequency of repetition of reported barrier by experts was 15 , which means around one third of the total experts identified the case as a barrier. Lack of databases bank, information and dissemination systems on work-related injuries and illnesses and other safety and health related information (insufficient information and publication sources and information technology) and shortage of skilled and efficient manpower in safety and health profession both got the lowest acceptable level of frequencies and expressed by 15 experts (31.2\%) (Table 2).

Table 3 shows a model of categorizing barriers towards establishment of OSH in developing countries based on the type of barriers. It shows that seven items were related to structural context like inadequacy of the inspection system, existence of constraints and weak economic, failure to promote a culture of prevention, social, economic and managerial underdevelopment, lack of information and dissemination systems, lack of legislation on occupational safety and health, absence or lack of national standards and basic or applied research with a mean degree of im- 
portance of 6.2 (Table 3).

Six items were related to managerial barriers like considering safety and health issues as cost rather than investment, lack of a coherent plan or strategy, lack of involvement of governments along with employers and employees on establishment of occupational safety and health, ignoring protection of human resources, lack of a single stewardship in safety and health and shortage of skilled and efficient manpower with a mean degree of importance of 6.2.

Four items were related to the implementation and execution of OSH standards like lack of awareness and knowledge towards work safety and occupational health, insufficient knowledge and skills of graduates in this field, non-compliance with laws and regulations, and lack of knowledge towards duties about implementations of the labour law with a mean degree of importance, with a mean degree of importance of 6.5 (Table 3).

Also, the barriers were classified, subjectively under "legislation and enforcement", "economic issues", "sociocultural issues", and "educational issues" categories. Six barriers were due to inappropriate legislation and enforcement, five barriers were due to sociocultural issues, three barriers were due to educational issues, two barriers were due to economic issues and one barrier was due to scientific and technical issues (Table 3).

\section{Discussion}

While in developed countries like US, the OSH administration has been created and employers are subject to its inspections and obliged to a set of comprehensive rules and regulations in order to enhance safety in the workplace, in most developing countries comprehensive and universal safety regulations have not been developed or enforced and typically, labourers are not trained in safe work practices, and there is lack of management commitment to safety programs and procedures ${ }^{14)}$. Lack or improper establishment of OSH system endanger life of million labours in many developing countries. About half of ILO conventions and protocols are totally or partially related to the subject of occupational safety and health, like ILO's OSH Convention (No. 187, 2006) which called for coherent and systematic treatment of OSH issues and Occupational Safety and Health Convention (No. 129, 1969), convention (No 155, 1981), which contain the main key strategic approvals on safety and health issues and its related protocol on 2002, protocol (No 164, 1981) $)^{2,6-8)}$.

Based on knowledge of the authors, this is the first
Iranian study that tried to get a consensus of the highqualified experts in the field of OSH with long term experience of administrative work in this field on the subject of barriers towards establishment of OSH in developing countries. Considering that these experts were located in a vast geographical area all around Iran, Delphi technique was used to obtain this consensus. The study results yield 17 barriers, which were repeated more than 15 times in the experts' opinions.

The results of this study showed that all experts believed lack of awareness and knowledge of employers, managers and health workers towards work safety and occupational health is one of the main barriers in establishment of OSH. This finding is aligned with the resolutions adopted by the International Labour Conference at its 101st Session in Geneva, June 2012 that consisted a total section to education, training and skills, also ILO guideline which in Convention No 155 and 2002 protocol has emphasized the importance of education and training on safety and health as one of the important and basic principle in achieving $\mathrm{OSH}$ and consider expanding the training activities for workers, HSE officers and employers a necessity for all the work places ${ }^{2,6-8)}$. Also Seoul declaration has emphasized the training of workers and employers and managers as one of the main activities in the field of $\mathrm{OSH}^{2,6)}$.

Another interesting finding of this study was that $41.6 \%$ of experts believed that existence of this attitude that safety and health issues are considered as cost rather than investment among managers and employers is a barrier towards establishment of OSH in developing countries. This issue in the second round of Delphi was given the highest degree of importance of 7.16. In Istanbul declaration it was mentioned that poor safety culture in developing countries is a result of their attitude towards safety and health as a cost and not an investment ${ }^{2,6)}$.

Lack of adequate and effective inspection and supervision on OSH activities was another barriers stated by $97.9 \%$ of experts with a mean degree of importance of 7.16. Prevention of occupational accidents and injuries and work related diseases require work safety inspection. The Labour Inspection Convention, 1947 (No. 81) and Protocol of 1995 to the Labour Inspection Convention, 1947 (No. 81) of ILO has considered inspection as one of the main tools for protection of safety and health of workers.

One of the other issues raised by experts related to rules and regulation was lack, deficiency, weakness or absence of legislation on OSH (absence or lack of binding rules and lack of up-to-date regulations). This issue however was mentioned by $79.1 \%$ of experts, but in the second 
Table 3. Categorization of barriers towards establishment of occupational safety and health in developing countries (results of the Delphi study)

\begin{tabular}{|c|c|c|c|}
\hline & $\begin{array}{l}\text { Identifying model of barriers towards establishment of } \\
\text { occupational safety and health in developing countries }\end{array}$ & Category & $\begin{array}{l}\text { Mean degree } \\
\text { of importance }\end{array}$ \\
\hline \multicolumn{4}{|c|}{ Structural barriers } \\
\hline 1 & $\begin{array}{l}\text { Inadequacy of the inspection system, lack of adequate and effective inspection and } \\
\text { supervision on occupational safety and health activities }\end{array}$ & Legislation and enforcement & 7.13 \\
\hline 2 & Existence of financial constraints and weak economy & Economic issues & 6.76 \\
\hline 3 & $\begin{array}{l}\text { Failure to establish and promote a culture of prevention in the field of occupational safety and } \\
\text { health }\end{array}$ & Sociocultural issues & 6.30 \\
\hline 4 & $\begin{array}{l}\text { Social, economic and managerial underdevelopment (lack of proper infrastructures and } \\
\text { inadequate infrastructures) }\end{array}$ & Sociocultural issues & 6.16 \\
\hline 5 & $\begin{array}{l}\text { lack of databases bank, information and dissemination systems on work-related injuries and } \\
\text { illnesses and other safety and health related information (insufficient information and publication } \\
\text { sources and information technologies) }\end{array}$ & Sociocultural issues & 5.83 \\
\hline 6 & $\begin{array}{l}\text { Lack, deficiency, weakness or absence of legislation on occupational safety and health } \\
\text { (absence or lack of binding rules and lack of up-to-date regulations ) }\end{array}$ & Legislation and enforcement & 5.66 \\
\hline 7 & Absence or lack of national standards and basic or applied researches & Scientific issues & 5.48 \\
\hline \multicolumn{4}{|c|}{ Managerial barriers } \\
\hline & Considering safety and health issues as cost rather than investment & Sociocultural issues & 7.6 \\
\hline 2 & $\begin{array}{l}\text { Lack of a coherent plan, modern strategies and appropriate vision for occupational safety and } \\
\text { health programs ( lack of a comprehensive national program) }\end{array}$ & Legislation and enforcement & 6.74 \\
\hline 3 & $\begin{array}{l}\text { Lack of participation, interaction and active involvement of governments with employers and } \\
\text { employees on establishment of occupational safety and health }\end{array}$ & Legislation and enforcement & 6.18 \\
\hline 4 & $\begin{array}{l}\text { Ignoring needs to protect human resources because of high level of unemployment, economic } \\
\text { conditions and lack of knowledge }\end{array}$ & Economic issues & 5.83 \\
\hline 5 & $\begin{array}{l}\text { Multiplicity of occupational safety and health stewardship } \\
\text { (multiplicity of task -based organizations) }\end{array}$ & Sociocultural issues & 5.76 \\
\hline 6 & Shortage of skilled and efficient manpower in safety and health professions & Legislation and enforcement & 5 \\
\hline \multicolumn{4}{|c|}{ Implementation barriers } \\
\hline 1 & $\begin{array}{l}\text { Lack of awareness and knowledge of employers, managers, health workers towards work safety } \\
\text { and occupational health }\end{array}$ & Educational issues & 7.16 \\
\hline 2 & $\begin{array}{l}\text { Insufficient knowledge and skills of graduates, and sometimes irrelevancy of their knowledge to } \\
\text { the needs and requirements of workplaces }\end{array}$ & Educational issues & 6.6 \\
\hline 3 & $\begin{array}{l}\text { Non-compliance with laws and regulations, lack of enforcements due to ignorance, incorrect and } \\
\text { profitable relationships or corruptions }\end{array}$ & Legislation and enforcement & 6.06 \\
\hline 4 & $\begin{array}{l}\text { Lack of knowledge of employers and industry leaders and organizations managers of their duties } \\
\text { towards implementations of the labour law, and the consequences of non-compliance with } \\
\text { occupational safety and health regulations }\end{array}$ & Educational issues & 6.02 \\
\hline
\end{tabular}

round of Delphi, it was graded the lowest by a mean degree of importance of 5.7. While in the history of industrial countries, the rules and regulations related to safety of workers played a crucial role in labour protection and $\mathrm{OSH}$, in developing countries the rules and regulations did not developed in the speed of the development in industrialization.

Existence of financial constraints and weak economy was another important issue, which $70.8 \%$ of experts mentioned it and its degree of importance in the second round of Delphi, was equal to 6.8, which shows the important role of economic status on establishment of health and safety. In the XIX World Congress on Safety and Health at Work, it was stated that the negative effects arising from the economic downturn, increases high risk jobs, temporary employment contracts, having multiple jobs, selfemployment, informal employment and temporary alliances, which all resulted in mental disorders, occupational and non-occupational accidents and diseases ${ }^{2,6)}$.

However "shortage of skilled and efficient manpower 
in safety and health profession" was considered as a barrier by $31.2 \%$ of experts and was given a mean degree of importance of five, but this is an important issue that can play a vital role in lack of establishment of OSH.

In general, most of the barriers that was identified by Iranian experts were aligned with the content of international conventions and guidelines and experts' views in other countries, which have been frequently stated by different words or phrases, but all of them emphasized that implementing these issues should be indigenous and consider the special economic, climatic, occupational issues and national capacities for combating these problems in each country ${ }^{15,16)}$.

Categorizing the main barriers showed that the maximum number of barriers was in the category of structural barriers followed by managerial barriers and the least number was related to implementation barriers; however mean degree of importance of implementation barriers were higher compared to structural and managerial barriers. This finding may mean that although the number of issues and barriers in structure and management of safety and health is more, but implementation plays an important role in establishment of safety and health in work places. Therefore, strengthening the legislation and enforcement of rules and regulation and improvement of overall safety culture in the society and raising awareness among employees, employers and policy makers could help improvement of OSH stablishment in the developing countries.

\section{References}

1) World of work report (2012) Better jobs for a better economy/International Labour Office, International Institute for Labour Studies.-Geneva: ILO, 2012. http://www. ilo.org/wcmsp5/groups/public/@dgreports/@dcomm/@ publ/documents/publication/wcms_179453.pdf. Accessed November 21, 2013.

2) International Labour Organization Plan Safe, Plan Healthy. Guidelines for Developing National Programmes on OSH (2013) http://www.ilo.org/wcmsp5/groups/public/_ed_ protect/—protrav/—safework/documents/publication/ wcms_214166.pdf. Accessed Novemeber 21, 2013.

3) International Labour Organization Safety in numbers. Pointers for a global safety culture at work, Geneva, 2003. http://www.ilo.org/wcmsp5/groups/public/—ed_protect/protrav/—safework/documents/publication/wcms_142840. pdf. Accessed November 21, 2013.

4) Petersen DC, Heinrich HW, Roos NR (1980) Industrial accident prevention: A safety management approach, 5th Ed. McGraw-Hill, New York.

5) International Institute for Labour Studies (ILO) Publications
(1988) Safety, health and working conditions in the transfer of technology to developing countries. http://www.ilo.org/ wcmsp5/groups/public/@ed_protect/@protrav/@safework/ documents/normativeinstrument/wcms_107831.pdf. Accessed November 21, 2013.

6) International Labour Organization Seoul Declaration on Safety and Health at Work in June 2008 during the XVIII World Congress. http://www.ilo.org/wcmsp5/groups/ public/@dgreports/@dcomm/documents/statement/ wcms_095910.pdf. Accessed November 17, 2010.

7) International Labour Organization P081—Protocol of 1995 to the Labour Inspection Convention, 1947 Protocol of 1995 to the Labour Inspection Convention, 1947 (Entry into force: 09 Jun 1998) Adoption: Geneva, 82nd ILC session (22 Jun 1995) http://www.ilo.org/dyn/normlex/en/f?p=NORM LEXPUB:12100:0:NO:P12100_ILO_CODE:P081, ILO. Accessed November 21, 2013.

8) International Labour Organization C129. Labour Inspection (Agriculture) Convention, (1969) (No. 129) Convention concerning Labour Inspection in Agriculture (Entry into force: 19 Jan 1972) Adoption: Geneva, 53rd ILC session (25 Jun 1969)—Status: Up-to-date instrument (Governance (Priority) Convention). http://www.ilo.org/dyn/normlex/ en/f? $\mathrm{p}=$ NORMLEXPUB: $12100: 0: N O: P 12100 \_I L O$ CODE:C129. Accessed November 20, 2013.

9) International Labour Organization (2001) Guidelines on OSH management systems. http://www.ilo.org/public/ english/region/afpro/cairo/downloads/wcms_107727.pdf. Accessed November 18, 2011.

10) International Labour Organization ILO introductory report (2011) Global trends and challenges on occupational safety and health: XIX World Congress on Safety and Health at Work: Istanbul Turkey, 11-15 September 2011. http://www. ilo.org/wcmsp5/groups/public/@ed_protect/@protrav/@ safework/documents/publication/wcms_162662.pdf. Accessed January 18, 2012.

11) Toyserkanmanesh $\mathrm{R}$ (2006) OSH management system in Iran, APO training course on the OSH management system: OHSAS 18001, Nadi, Fiji.

12) Dalkey N, Helmer O (1963) An experimental application of the Delphi Method to the use of experts. Manage Sci $\mathbf{9}$, 458-67. [CrossRef]

13) Rowe G, Wright G (1999) The Delphi technique as a forecasting tool: issues and analysis. Int J Forecast 15, 353-7. [CrossRef]

14) Koehn EE, Kothari RK, Pan CS (1995) Safety in developing countries: professional and bureaucratic problems. J Constr Eng Manage 121, 261-5. [CrossRef]

15) Madbuli HN, Mustafa MA, Al-Darrab AA, Zytoon MA (2013) OSH performance of the manufacturing sector in Jeddah Industrial Estate, Saudi Arabia: a 20-years followup study. Saf Sci 53, 11-24. [CrossRef]

16) Vinodkumar MN, Bhasi M (2011) A study on the impact of management system certification on safety management. Saf Sci 49, 498-507. [CrossRef] 